\title{
Profitabilitas, Ukuran Perusahaan, Umur Perusahaan, Kepemilikan Institusional dan Pengungkapan Sustainability Report
}

\author{
Ni Kadek Novita Madani ${ }^{1}$ \\ Fakultas Ekonomi dan Bisnis \\ Universitas Udayana, Indonesia
}

\author{
Gayatri ${ }^{2}$ \\ Fakultas Ekonomi dan Bisnis \\ Universitas Udayana, Indonesia
}

Surel : novitamadani1998@gmail.com

\section{ABSTRAK}

Sustainability report merupakan sebuah laporan terukur yang dipublikasikan perusahaan terkait dampak ekonomi, sosial, dan lingkungan akibat aktivitas perusahaan. Penelitian ini bertujuan untuk mencari pengaruh profitabilitas, ukuran perusahan, umur perusahaan, dan kepemilikan institusional pada pengungkapan sustainability report. Populasi dalam penelitian ini adalah perusahaan yang terdaftar di bursa efek Indonesia pada tahun 2016-2019 dan menerbitkan sustainability report sebagai sampel. Metode penentuan sampel menggunakan teknik purposive sampling yang menghasilkan 21 perusahaan dengan 77 pengamatan. Teknik analisis data menggunakan analisis regresi linier berganda yang menghasilkan profitabilitas berpengaruh tidak signifikan pada pengungkapan sustainability report, ukuran perusahaan bernilai negatif signifikan pada pengungkapan sustainability report, umur perusahaan berpengaruh positif signifikan pada pengungkapan sustainability report, dan kepemilikan institusional berpengaruh tidak signifikan pada pengungkapan sustainability report.

Kata Kunci: Sustainability; Profitabilitas; Ukuran; Umur; Institusional.

\section{Profitability, Company Size, Company Age, Institutional Ownership and Sustainability Report Disclosures}

\begin{abstract}
Sustainability report is measurable report that published by company regarding the economic, social, and environmental impacts of the company's activity. This study aims to find the effect of profitability, company size, company age, and institutional ownership on sustainability report disclosures. The populations were listed companies on Indonesia stock exchange in 2016-2019 and published sustainability report as a sample. The method of determining sample using purposive sampling technique which is resulted 21 companies with 77 observations. The data analysis technique using multiple linier regression analysis which results profitability have no significant effect on sustainability report disclosure, company size in negative significant effect on sustainability report, companyaage have positive significant effect on sustainability report, and institutional ownership have no significant effectaon the sustainability report disclosure.
\end{abstract}

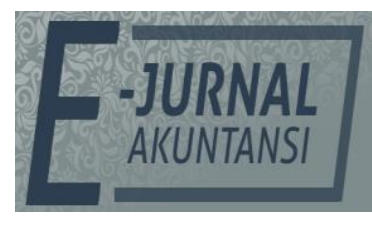

e-ISSN 2302-8556

Vol. 31 No. 4

Denpasar, April 2021

Hal. 822-835

DOI:

10.24843/EJA.2021.v31.i04.p03

PENGUTIPAN:

Madani, N.K.N., \& Gayatri (2021). Profitabilitas, Ukuran Perusahaan, Umur

Perusahaan, Kepemilikan Institusional dan

Pengungkapan Sustainability Report. E-Jurnal Akuntansi, 31(4), 822-835

RIWAYAT ARTIKEL: Artikel Masuk: 19 September 2020 Artikel Diterima: 19 Februari 2021

Keywords: Sustainability; Profitability; Size; Age; Institutional.

Artikel dapat diakses : https://ojs.unud.ac.id/index.php/Akuntansi/index 


\section{PENDAHULUAN}

Pembaharuan suatu daerah seringkali didorong oleh eksistensi perusahaan maupun industri yang beroperasi di lokasi tersebut (Dewi, 2019). Hal tersebut tentu dapat menciptakan lapangan pekerjaan bagi masyarakat sekitar, namun disamping itu juga dapat menimbulkan dampak negatif dikarenakan tingginya keinginan perusahaan dalam menghasilkan keuntungan dapat memicu kerusakan lingkungan yang nantinya berimbas pada masyarakat sekitar, salah satunya adalah polusi industri yang mengancam sumber-sumber air. Selain itu, di sepanjang tahun 2017 wahana lingkungan hidup juga mencatat sebanyak 307 konflik lingkungan dan agraria yang bersumber dari 13 provinsi di Indonesia (Rahmadi, 2018).

Kasus-kasus yang diakibatkan oleh perusahaan tersebut dideskripsikan melalui film dokumenter Indonesia berjudul "Sexy Killer" yang menggambarkan kesulitan masyarakat Kalimantan akibat perluasan lahan oleh perusahaan tambang maupun keberadaan perusahaan listrik tenaga uap Batang yang menyebabkan terhambatnya kegiatan petani dan nelayan sekitar. Padahal sudah terdapat undang-undang nomor 40 tahun 2007 pasal 74 yang menyatakan setiap perusahaan yangamelaksanakan aktivitasnya pada aspek yang bersumber dari alam harus melakukan aktivitas yang berhubungan dengan lingkungan dan sosial (Marthin et al., 2017). Akan tetapi, terbatasnya ulasan informasi guna menafsirkan dampak dari lingkungan dan sosial tersebut menyebabkan pemerintah tidak bisa memantau sejauh mana tanggung jawab perusahaan pada keberlangsungan lingkungan dan sosial akibat aktivitasnya (Budirahardjo, 2019). Adanya kejadian tersebut, memunculkan kebingungan pada perusahaan bagaimana cara membuktikan tanggung jawabnya pada pembangunan keberlanjutan tanpa menurunkan keyakinan pada keberlangsungan usahanya. Hal itu sejalan dengan teori legitimasi yang menegaskan bahwa setiap perusahaan bisa terus bertahan apabila masyarakat menyadari aktivitasnya sesuai dengan sistem nilai dari masyarakat itu sendiri (Dewi, 2019). Dan teori stakeholder yang menegaskan bahwa perusahaan bukanlah entitas yang bergerak hanya untuk kepentingannya saja namun juga wajib memberi keuntungan pada para stakeholder (Manurung \& Muid, 2015). Oleh sebab itu, dibutuhkan kebijakan dalam mengelola laporan secara rinci serta bisa dijadikan daftar perhitungan untuk menafsirkan tanggung jawab antar perusahaan. Dengan demikian, sustainability report merupakan jawaban untuk mengatasi kebingungan yang dirasakan oleh perusahaan.

Sustainability report merupakan sebuah laporan terukur yang dipublikasikan perusahaan terkait dampak ekonomi, sosial, dan lingkungan akibat aktivitas perusahaan yang memiliki tujuan untuk memakmurkan ekonomi tanpa mencemari lingkungan (Massa et al., 2015). Hal tersebut sejalan dengan konsep triple bottom lines yang menyatakan bahwa perusahaan ingin tetap diterima dalam jangka panjang hendaknya tidak hanya mementingkan keuntungan yang akan diperoleh, namun juga harus mulai memerhatikan aspek sosial dan lingkungan di tempat perusahaan berdiri. Dengan mengungkapkan sustainability report selain menjalin hubungan baik dengan stakeholder (Adiatma \& Suryanawa, 2018) juga dapat menambah nilai positif untuk menumbuhkan kepercayaan masyarakat yang nantinya akan meningkatkan keuangan untuk 
jangka panjang (Amran \& Ooi, 2016). Namun, di Indonesia pengungkapannya masih bersifat sukarela karena belum memiliki standar yang berlaku menyeluruh (Syofyan, 2016) sehingga menyebabkan banyak perusahaan belum mengungkapkan sustainability report.

Perusahaan dengan tingkat profitabilitas tinggi dianggap dapat mencerminkan kinerja finansial karena dapat menggambarkan kemampuan perusahaan dalam menghasilkan keuntungan (Gunawan et al., 2018) yang nantinya akan berpengaruh pada aktivitas sosial dan lingkungan yang akan dilaksanakan perusahaan. Sebaliknya jika profit yang dihasilkan rendah, maka perusahaan akan meyusutkan biaya sosialnya dengan cara meminimalisasi jumlah informasi pada sustainability report untuk tetap menjaga hubungan dengan stakeholder. Dengan demikian, stakeholder tentu merasa bahwa modal yang dipercayakan pada perusahaan sudah terkelola dengan baik.

Pada umumnya, perusahaan besar akan melaksanakan lebih banyak aktivitas yang nantinya akan menimbulkan dampak lebih besar pada masyarakat. Oleh sebab itu, perusahaan besar akan mendapat lebih banyak perhatian publik dibandingkan perusahaan kecil (Hidayat, 2017) sehingga ukuran perusahaan dapat dikatakan sangat memengaruhi peningkatan pengungkapan informasi sosial dan lingkungan karena semakin besar ukuran perusahaan akan mengharuskannya untuk melaksanakan aktivitas-aktivitas sosial dan lingkungan (Liana, 2019).

Secara teori, dapat dikatakan bahwa kemajuan dari perusahaan berhubungan dengan bertambahnya umur perusahaan itu sendiri karena pertumbuhan umur tersebut akan disertai dengan peralihan perilaku yang bergerak menuju kemajuan (Munsaidah, 2016). Dengan demikian, lamanya umur perusahaan akan menambah kemungkinan perusahaan untuk melaksanakan aktivitas sosial dan lingkungan sebagai wujud komitmennya agar dapat mempertahankan kepercayaan yang telah diberikan oleh masyarakat (Sunaryo \& Mahfud, 2016).

Presentase kepemilikan saham dapat menentukan komposisi kepemilikan yang ada pada perusahaan, salah satunya adalah saham yang dimiliki oleh institusi. Adanya kepemilikan saham oleh institusi dalam perusahaan dapat mengawasi jalannya perusahaan dengan kompeten sehingga pengendalian terhadap perusahaan sangat tinggi (Sunarwijaya, 2017). Dengan demikian, kepemilikan institusional yang tinggi dalam perusahaan bisa memberi tekanan yang besar juga pada perusahaan, seperti untuk melaksanakan akivitas sosial dan lingkungna dikarenakan investor institusional cenderung memilih menginvestasikan uangnya padaaperusahaan dengan pencapaian sosial bagus.

Berdasarkan uraian latar belakang tersebut, penelitian ini bertujuan untuk mengkaji secara empiris pengaruh variabel profitabilitas, ukuran perusahaan, umur perusahaan, dan kepemilikan institusional pada pengungkapan sustainability report. Penelitian tentang pengungkapan sustainability report ini penting dilakukan agar pencemaran lingkungan akibat kegiatan operasi perusahaan dapat dipertanggungjawabkan sehingga mengurangi kerugian yang dirasakan pihak-pihak yang tinggal berdekatan dengan perusahaan. 
Legitimasi adalah salah satu penunjang bertahannya sebuah perusahaan dalam dunia bisnis, dikarenakan legitimasi mengandung batasan yang bersumber dari norma serta nilai sosial yang dapat menjadi pendorong analisa perilaku perusahaan untuk memerhatikan lingkungan dan sosial (Dowling \& Pfeffer, 1975). Dalam teori legitimasi, dijelaskan bahwa perusahaan akan selalu konsisten untuk memastikan operasinya berjalan sesuai dengan norma yang berlaku di masyarakat (Solikhah, 2016). Oleh sebab itu, perusahaan akan lebih peduli pada lingkungan dimana mereka beroperasi.

Teori stakeholder merupakan teori yang menyatakan tanggung jawab perusahaan pada kalangan yang berkepentingan (Freeman, 1984) dikarenakan perusahaan beroperasi bukan hanya untuk kepentingannya sendiri, namun juga dapat memberi keuntungan pada stakeholder. Oleh karena itu, untuk tetap menjalin hubungan dengan stakeholder (Dwipayadnya et al., 2015) perusahaan akan lebih banyak mengungkapkan informasi terkait aktivitasnya termasuk kepeduliannya pada lingkungan dan sosial. Dengan demikian, dukungan dari para stakeholder sangat memengaruhi keberadaan suatu perusahaan.

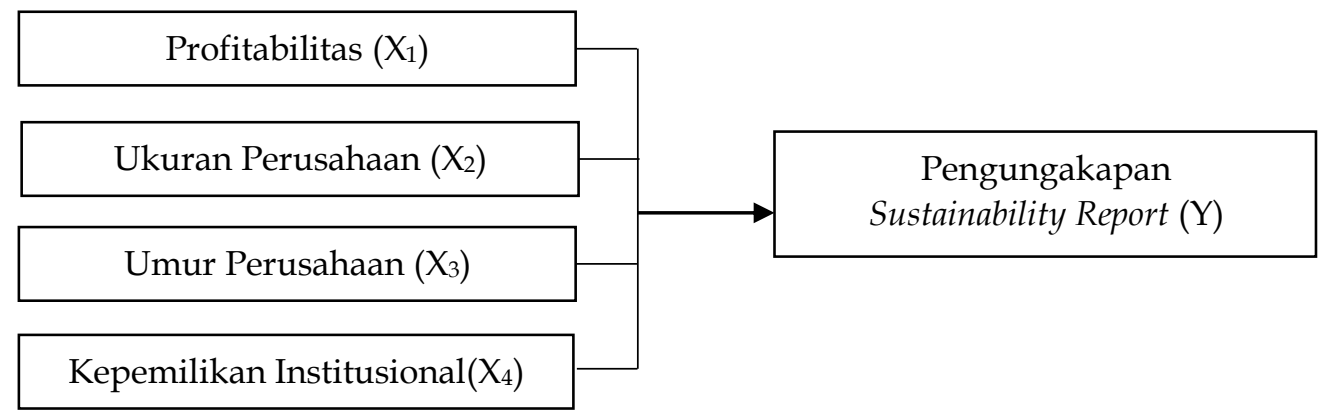

Gambar 1. Model Penelitian

Sumber: Data Penelitian, 2020

Perusahaan dengan profitabilitas tinggi cenderung mempunyai anggaran untuk mengungkapkan lebih banyak informasi sosial (Meutia, 2019) ke dalam sustainability report agar dapat menunjukkan pada stakeholder bahwa operasinya berjalan efisien. Dengan demikian, sesuai dengan teori stakeholder mengharuskan perusahaan untuk lebih aktif melaksanakan aktivitas sosial karena stakeholder akan menginginkan informasi terkait kegiatann yang dilakukan perusahaan. Berdasarkan penelitian terdahulu yang dilakukan Lucia \& Panggabean (2018), Meutia (2019), dan Liana (2019) menyatakan terdapat hubungan positif antara variabel profitabilitas dengan pengungkapan sustainability report sehingga hipotesis yanga bisa dikembangkan adalah sebagai berikut.

$\mathrm{H}_{1}$ : Profitabilitas berpengaruh positif pada pengungkapan sustainability report.

Pada umumnya, semakinabesar ukuran perusahaanaakan berpengaruh pada luas pengungkapan informasi ke dalam sustainability report (Khafid, 2015). Hal tersebut dikarenakan perusahaan besar melaksanakan lebih banyak aktivitas yang nantinya akan berpengaruh lebih besar pada masyarakat dibandingkan perusahaan kecil (Mapparessa et al., 2017) sehingga menjadikannya lebih diperhatikan oleh publik. Oleh sebab itu, perusahaan besar akan mengeluarkan lebih banyak biaya sosial agar dapat mengungkapkan lebih banyak aktivitas sosialnya ke dalam sustainability report. Hal tersebut berhubungan dengan teori legitimasi, dimana ukuran perusahaan tidak terlepas dari peran lingkungan serta 
masyarakat sehingga perusahaan harus tetap menyelaraskan aktivitasnya sesuai dengan nilai yang yang berada di masyarakat. Berdasarkan penelitian terdahulu yang dilakukan Afsari \& Purnamawati (2017), Barung (2018), dan Setiawan (2019) menyatakan terdapat hubungan positif antara variabel ukuran perusahaan dengan pengungkapan sustainability report sehingga hipotesisi yang bisa dikembangkan adalah sebagai berikut.

$\mathrm{H}_{2}$ : Ukuran perusahaan berpengaruh positif pada pengungkapan sustainability report.

Perusahaan yang telah lama beroperasi tentu mempunyai lebih banyak pengalaman untuk mempertahankan bisnisnya (Elshabasy, 2018) sehingga akan cenderung menunjukkan kepeduliannya terhadap lingkungan dan sosial dengan mengungkapkan lebih banyak informasi ke dalam sustainability report. Dengan demikian, perusahaan akan tetap memperoleh kepercayaan publik. Oleh sebab itu, dapat dikaitkan dengan teori legitimasi yang mengharuskan perusahaan untuk melaksanakan aktivitas sosial dan lingkungan untuk mempertahankan kepercayaan yang telah diperoleh perusahaan. Berdasarkan penelitian terdahulu yang dilakukan Bhatia \& Tuli (2017) serta Orazalin \& Mahmood (2018) menyatakan terdapat hubungan positifaantara variabel umur perusahaan dengan pengungkapan sustainability report sehingga hipotesis yang bisa dikembangkan adalah sebagai berikut.

$\mathrm{H}_{3}$ : Umur perusahaan berpengaruh positif pada pengungkapan sustainability report.

Kepemilikan institusional diduga merupakan pihak-pihak yang dapat memantau jalannya perusahaan karena bersifat independen sehigga dapat melakukan pengawasan pada perusahaan. Dengan mengungkapkan sustainability report kepada publik dianggap sebagai salah satu usaha perusahaan untuk menyelaraskan diri dengan lingkungan dan sosial di wilayah perusahaan berdiri. Selain, itu, juga dapat menunjukkan pada investor institusional bahwa perusahaan memiliki pencapaian sosial yang baik (Majeed et al., 2015) sehingga investor institusional akan merasa tidak salah untuk menginvestasikan uangnya pada perusahaan. Hal tersebut berhubungan dengan teori stakeholder, dimana tingkat kepemilikan institusional yang tinggi akan menjadikan investor institusional lebih mengawasi jalannya perusahaan sehingga dapat mendorong perusahaan untuk melaksanakan aktivitas sosial. Berdasarkan penelitian terdahulu yang dilakukan Rohmah (2016), Aliniar (2017), dan Novitaningrum (2017) menyatakan bahwa terdapat hubungan positif antara variabel kepemilikan institusional dengan pengungkapan sustainability report sehingga hipotesis yang dapat dikembangkan adalah sebagai berikut.

$\mathrm{H}_{4}$ : Kepemilikan institusional berpengaruh positif pada pengungkapan sustainability report.

\section{METODE PENELITIAN}

Penelitian ini merupakan penelitian kuantitatif yang berbentuk asosiatif. Penelitian ini dilakukan pada perusahaan yang terdaftar di bursa efek Indonesia yang diakses melalui situs resmi bursa efek Indonesia yaitu www.idx.co.id. Dalam penelitian ini yang digunakan sebagai objek penelitian adalah pengaruh profitabilitas, ukuran perusahaan, umur perusahaan, dan kepemilikan 
institusional pada pengungkapan sustainability report. Jenis data dalam penelitian ini menggunakan data kuantitatif yang bersumber dari data sekunder berupa laporan tahunan yang diperoleh dari bursa efek Indonesia.

Populasi dalam penelitian ini adalah perusahaan yang terdaftar di bursa efek Indonesia pada tahun 2016-2019 dan perusahaan yang menerbitkan sustainability report pada tahun 2016-2019 sebagai sampel. Penelitian ini menggunakan metode nonprobability sampling dengan teknik purposive sampling sebagai metode penentuan sampel yang menghasilkan 21 perusahaan dengan 77 pengamatan. Adapun kriteria dalam menentukan sampel dalam penelitian ini adalah sebagai berikut, 1) Perusahaan yang menerbitkan sustainability report pada tahun 2016-2019, 2) Perusahaan yang menerbitkan laporan tahunan berturutturut pada tahun 2016-2019.

Pengungkapan sustainability report dalam penelitian ini diukur menggunakan indeks GRI G4 dengan 91 item pengungkapan (Setiawan, 2019), penghitungan profitabilitas diadalam penelitian diproksikan melalui rasio return on asset yang dapat memperlihatkan jumlah laba bersih yang diperoleh perusahaan (Meutia, 2019), variabel ukuran perusahaan dihitung melalui total aset yang dimiliki perusahaan yang kemudian ditransformasikan ke dalam bentuk logaritma dikarenakan nilainya yang cenderung lebih besar daripada variabel lain dalam penelitian ini (Barung, 2018), variabel umur perusahaan dihitung melalui tanggal terdaftarnya perusahaan di bursa efek Indonesia hingga dilakukannya penelitian (Wijayana, 2018), dan variabel kepemilikan institusional dihitung melalui presentase saham milik institusional dengan total saham yang diterbitkan (Situmorang, 2016).

Penelitian ini menggunakan analisis regresi linier berganda dengan bantuan program stastisical produst and service solutions sebagai teknik analisis data. Sebelum model regresi digunakan untuk menguji hipotesis, dilakukan uji asumsi klasik terlebih dulu. Berikut rumus persamaan analisis regresi linier berganda, yaitu :

$Y=\alpha+\beta_{1} X_{1}+\beta_{2} X_{2}+\beta_{3} X_{3}+\beta_{4} X_{4}+\varepsilon$

Keterangan :

Y = Pengungkapan Sustainability Report

a $\quad=$ Konstanta

$\beta_{1,2,3,4}=$ Koefisien Regresi dari Variabel Independen

$\varepsilon \quad=$ error term

$\mathrm{X}_{1} \quad=$ Profitabilitas

$\mathrm{X}_{2}=$ Ukuran Perusahaan

$\mathrm{X}_{3}=$ Umur Perusahaan

$\mathrm{X}_{4} \quad=$ Kepemilikan Institusional

\section{HASIL DAN PEMBAHASAN}

Pemilihan sampel dalam penelitian ini ditentukan dengan menggunakan metode purposive sampling dengan menggunakan beberapa kriteria. Pengambilan sampel ini digambarkan pada Tabel 1. 
Tabel 1. Ringkasan Perolehan Sampel Penelitian

\begin{tabular}{lll}
\hline No. & Keterangan & Jumlah \\
\hline 1. & Perusahaan yang terdaftar di BEI periode 2016-2019 & 528 \\
2. & Perusahaan yang tidak menerbitkan sustainability report berturut-turut & $(507)$ \\
& selama periode 2016-2019 & 21 \\
& Jumlah sampel perusahaan & 84 \\
& Jumlah observasi selama empat tahun & 7 \\
Data outlier & 77 \\
Jumlah data observasi & \\
\hline
\end{tabular}

Sumber: Data Penelitian, 2020

Nilai rata-rata (mean), nilai minimun, nilai maksimum, dan standar deviasi dari masing-masing variabel penelitian dapat dilihat pada Tabel 2 . Berdasarkan hasil pengujian statistik deskriptif dalam Tabel 2, maka dapat dijelaskan nilai statistik deskriptif variabel pengungkapan sustainability report memiliki nilai minimum sebesar 0.077 , nilai maksimum sebesar 0.505 , nilai mean sebesar 0.22713 , dan nilai standar deviasi sebesar 0.100063 . Variabel profitabilitas memiliki nilai minimum sebesar -0.057 , nilai maksimum sebesar 0.186 , nilai mean sebesar 0.03670, dan nilai standar deviasi sebesar 0.044667. Variabel ukuran perusahaan memiliki nilai minimum sebesar 29.171, nilai maksimum sebesar 34.887, nilai mean sebesar 31.74273, dan nilai standar deviasi sebesar 1.495790 . Variabel umur perusahaan memiliki nilai minimum sebesar 2, nilai maksimum sebesar 30, nilai mean sebesar 18.35, dan nilai standar deviasi sebesar 8.887. Variabel kepemilikan institusional memiliki nilai minimum sebesar 0.011, nilai maksimum sebesar 0.894, nilai mean sebesar 0.50423 , dan nilai standar deviasi sebesar 0.316629 .

Tabel 2. Hasil Uji Statistik Deskriptif

\begin{tabular}{llrrrr}
\hline & $\mathrm{N}$ & Minimum & Maximum & Mean & Std. Deviation \\
\hline Pengungkapan SR $(\mathrm{Y})$ & 77 & 0,077 & 0,505 & 0,227 & 0,100 \\
Profitabilitas $\left(\mathrm{X}_{1}\right.$ & 77 & $-0,057$ & 0,186 & 0,036 & 0,044 \\
Ukuran Perusahaan $\left(\mathrm{X}_{2}\right)$ & 77 & 29,171 & 34,887 & 31,742 & 1,495 \\
Umur Perusahaan $\left(\mathrm{X}_{3}\right)$ & 77 & 2,000 & 30,000 & 18,350 & 8,877 \\
Kepemilikan Institusional $\left(\mathrm{X}_{4}\right)$ & 77 & 0,011 & 0,894 & 0,504 & 0,316 \\
Valid N (listwise) & 77 & & & & \\
\hline
\end{tabular}

Sumber: Data Penelitian, 2020

Syarat yang harus dipenuhi untuk melakukan pengujian persamaan regresi berganda yakni memenuhi uji asumsi klasik. Tabel 3, menunjukkan bahwa hasil uji normalitas koefisien Asymp. Sig (2-tailed) memiliki nilai 0.174 sehingga data dalam penelitian ini berdistribusi normal.

Tabel 3. Hasil Uji Normalitas

\begin{tabular}{lc}
\hline & Unstandardized Residual \\
\hline $\mathrm{N}$ & 77 \\
Kologorov-Smirnov Z & 1.105 \\
Asymp. Sig. (2-tailed) & 0.174 \\
\hline
\end{tabular}

Sumber: Data Penelitian, 2020

Tabel 4, menunjukkan nilai tolerance masing-masing variabel lebih dari 0.10 kemudian nilai Variance Inflation Factor (VIF) masing-masing variabel kurang dari 10.00 yang artinya antar variabel bebas tidak terjadi gejala multikolonearitas. 
Tabel 4. Hasil Uji Multikolinearitas

\begin{tabular}{lrr}
\hline & \multicolumn{2}{c}{ Collinearity Statistics } \\
\cline { 2 - 3 } Model & Tolerance & VIF \\
\hline Profitabilitas $\left(\mathrm{X}_{1}\right)$ & 0.920 & 1.087 \\
Ukuran Perusahaan $\left(\mathrm{X}_{2}\right)$ & 0.853 & 1.173 \\
Umur Perusahaan $\left(\mathrm{X}_{3}\right)$ & 0.802 & 1.248 \\
Kepemilikan Institusional $\left(\mathrm{X}_{4}\right)$ & 0.796 & 1.256 \\
\hline
\end{tabular}

Sumber: Data Penelitian, 2020

Tabel 5, menunjukkan bahwa nilai signifikansi masing-masing variabel lebih dari 0.05 yang artinya model regresi dalam penelitian ini bebas dari gejala heteroskedastisitas.

Tabel 5. Hasil Uji Heteroskedastisitas

\begin{tabular}{ll}
\hline Model & Sig. \\
\hline Profitabilitas $\left(\mathrm{X}_{1}\right)$ & 0.426 \\
Ukuran Perusahaan $\left(\mathrm{X}_{2}\right)$ & 0.554 \\
Umur Perusahaan $\left(\mathrm{X}_{3}\right)$ & 0.068 \\
Kepemilikan Institusional $\left(\mathrm{X}_{3}\right)$ & 0.138 \\
\hline
\end{tabular}

Sumber: Data Penelitian, 2020

Tabel 6, menunjukkan bahwa nilai Sig. (2-tailed) pada uji Run Test sebesar 0.206 yang lebih besar dari 0.05 , maka dapat disimpulkan bahwa tidak terdapat autokorelasi antar nilai residual pada penelitian ini.

Tabel 6. Hasil Uji Autokorelasi dengan Run Test

\begin{tabular}{lc}
\hline & $\begin{array}{c}\text { Unstandardized } \\
\text { Residual }\end{array}$ \\
\hline Test Value & -0.02725 \\
Cases $<$ Test Value & 38 \\
Cases $>=$ Test Value & 39 \\
Total Cases & 77 \\
Number of Runs & 45 \\
Z & 1.264 \\
Asymp. Sig. (2-tailed) & 0.206
\end{tabular}

Sumber: Data Penelitian, 2020

Berdasarkan uji asumsi klasik, diketahui bahwa data dalam penelitian ini terdistribusi dengan normal, bebas dari multikolinearitas, tidak terjadi heteroskedastisitas, dan tidak terdapat autokorelasi, maka data yang tersedia telah memenuhi syarat untuk menggunakan model regresi linier berganda.

Tabel 7. Hasil Uji Analisis Regresi Linier Berganda

\begin{tabular}{|c|c|c|c|c|c|}
\hline \multirow[b]{2}{*}{ Model } & \multicolumn{2}{|c|}{$\begin{array}{l}\text { Unstandardized } \\
\text { Coefficients }\end{array}$} & \multirow{2}{*}{$\begin{array}{l}\text { Standardized } \\
\text { Coefficients } \\
\text { Beta }\end{array}$} & \multirow[b]{2}{*}{$\mathrm{T}$} & \multirow[b]{2}{*}{ Sig. } \\
\hline & B & Std. Error & & & \\
\hline 1 (Constant) & 0.890 & 0.250 & & 3.562 & 0.001 \\
\hline Profitabilitas $\left(\mathrm{X}_{1}\right)$ & -0.148 & 0.251 & -0.066 & -0.590 & 0.557 \\
\hline Ukuran Perusahaan $\left(\mathrm{X}_{2}\right)$ & -0.023 & 0.008 & -0.350 & -3.008 & 0.004 \\
\hline Umur Perusahaan $\left(X_{3}\right)$ & 0.003 & 0.001 & 0.270 & 2.245 & 0.028 \\
\hline Kepemilikan & 0.060 & 0.038 & 0.190 & 1.572 & 0.120 \\
\hline
\end{tabular}

Institusional $\left(X_{3}\right)$

Sumber: Data Penelitian, 2020 
Berdasarkan Tabel 7, diperoleh model regresi berganda yang terbentuk pada penelitian ini adalah sebagai berikut.

$$
\mathrm{Y}=0.890-0.148 \mathrm{X}_{1}-0.023 \mathrm{X}_{2}+0.003 \mathrm{X}_{3}+0.060 \mathrm{X}_{4}
$$

Nilai konstanta bernilai positif sebesar 0.890 menunjukkan apabila variabel independen terdiri dari profitabilitas, ukuran perusahaan, umur perusahaan, dan kepemilikan institusional diasumsikan nilainya konstan, maka nilai konstanta dari variabel pengungkapan sustainability report adalah sebesar 0.890. Nilai koefisien variabel profitabilitas bernilai negatif sebesar 0.148 memiliki arti apabila nilai profitabilitas naik satu persen, maka pengungkapan sustainability report akan turun sebesar 0.148. Nilai koefisien variabel ukuran perusahaan bernilai negatif sebesar 0.023 memiliki arti apabila nilai ukuran perusahaan naik satu persen, maka pengungkapan sustainability report akan turun sebesar 0.023. Nilai koefisien umur perusahaan bernilai positif sebesar 0.003 memiliki arti apabila nilai umur perusahaan naik satu persen, maka nilai sustainability report akan naik sebesar 0.003. Nilai koefisien variabel kepemilikan institusional bernilai positif sebesar 0.060 memiliki arti apabila nilai kepemilikan institusional naik satu persen, maka nilai sustainability report akan naik sebesar 0.060 .

Tabel 8, menjelaskan nilai Adjusted $R$ Square adalah 0.121. Hal ini berarti bahwa $12.1 \%$ variabel tingkat pengungkapan sustainability report dapat dijelaskan oleh keempat variabel independen, yaitu profitabilitas, ukuran perusahaan, umur perusahaan, dan kepemilikan institusional sedangkan sisanya, yatu sebesar $87.9 \%$ dijelaskan oleh variabel-variabel lain di luar model.

Tabel 8. Hasil Uji Koefisien Determinasi $\left(\mathbf{R}^{2}\right)$

\begin{tabular}{ccrrr}
\hline Model & $\mathrm{R}$ & $\mathrm{R}$ Square & $\begin{array}{c}\text { Adjusted } \mathrm{R} \\
\text { Square }\end{array}$ & $\begin{array}{c}\text { Std. Error of the } \\
\text { Estimate }\end{array}$ \\
\hline 1 & $0,409^{\mathrm{a}}$ & 0,167 & 0,121 & 0,093821 \\
\hline
\end{tabular}

Sumber: Data Penelitian, 2020

Tabel 9, menjelaskan bahwa nilai signifikansi yang diperoleh sebesar 0.010 yang lebih kecil daripada 0.05 dengan demikian, model regresi linier berganda layak digunakan atau variabel profitabilitas, ukuran perusahaan, umur perusahaan, dan kepemilikan institusional mampu menjelaskan variabel tingkat pengungkapan sustainability report.

Tabel 9. Hasil Uji Kelayakan Model (Uji F)

\begin{tabular}{llllll}
\hline Model & $\begin{array}{l}\text { Sum of } \\
\text { Squares }\end{array}$ & Df & $\begin{array}{l}\text { Mean } \\
\text { Square }\end{array}$ & F & Sig. \\
\hline 1 Regression & 0,127 & 4 & 0,032 & 3,613 & 0,010 \\
Residual & 0,634 & 72 & 0,009 & & \\
Total & 0,761 & 76 & & & \\
\hline
\end{tabular}

Sumber: Data Penelitian, 2020

Berdasrkan hasil yang diperoleh pada Tabel 7, hipotesis pertama menyatakan bahwa profitabilitas berpengaruh positif pada pengungkapan sustainability report. Berdasarkan hasil analisis regresi, diperoleh nilai signifikansi untuk profitabilitas sebesar 0.557 dan koefisien regresi sebesar -0.148 . Hal ini menunjukkan bahwa profitabilitas berpengaruh negatif dan tidak signifikan pada pengungkapan sustainability report sehingga $\mathrm{H}_{1}$ ditolak. Oleh sebab itu, hasil 
tersebut tidak berhasil membuktikan berlakunya teori stakeholder yang mendasari penelitian ini.

Profitabilitas tidak berpengaruh signifikan pada pengungkapan sustainability report mengindikasikan bahwa perusahaan yang memiliki profitabilitas tinggi belum tentu meningkatkan pengungkapan sustainability report. Hal tersebut dikarenakan laba yang dimiliki perusahaan lebih diprioritaskan untuk kepentingan operasional sehingga pemanfaatan untuk aktivitas sosial perusahaan lebih sedikit. Hasil penelitian ini konsisten dengan penelitian yang dilakukan oleh Ariyani \& Hartomo (2018) dan Sulistyawati \& Qadriatin (2018) yang menyatakan bahwa profitabilitas berpengaruh negatif dan tidak signifikan pada pengungkapan sustainability report.

Hipotesis kedua menyatakan bahwa ukuran perusahaan berpengaruh positif pada pengungkapan sustainability report. Berdasarkan hasil analisis regresi, diperoleh nilai signifikansi untuk ukuran perusahaan sebesar 0.004 dan koefisien regresi sebesar -0.023 . Hal ini menunjukkan bahwa ukuran perusahaan berpengaruh negatif dan signifikan pada pengungkapan sustainability report sehingga $\mathrm{H}_{2}$ ditolak. Oleh sebab itu, hasil tersebut tidak berhasil membuktikan berlakunya teori legitimasi yang mendasari penelitian ini.

Ukuran perusahaan berpengaruh negatif dan signifikan pada pengungkapan sustainability report mengindikasikan semakin besar ukuran perusahaan, maka semakin rendah jumlah pengungkapan di dalam sustainability report. Hal tersebut dikarenakan perusahaan besar telah memiliki citra yang baik di masyarakat dan telah mendapatkan legitimasi sehingga perusahaan besar tidak selalu mengungkapkan kinerja sosial dan lingkungannya untuk meyakinkan stakeholder maupun masyarakat. Hasil penelitian ini konsisten dengan penelitian yang dilakukan oleh Marwati \& Yulianti (2015) dan Diono (2017) yang menyatakan bahwa ukuran perusahaan berpengaruh negatif dan signifikan pada pengungkapan sustainability report.

Hipotesis ketiga menyatakan bahwa umur perusahaan berpengaruh positif pada pengungkapan sustainability report. Berdasarkan hasil analisis regresi, diperoleh nilai signifikansi 0.028 dan koefisien regresi sebesar 0.003 . Hal ini menunjukkan bahwa umur perusahaan berpengaruh positif dan signifikan pada pengungkapan sustainability report sehingga $\mathrm{H}_{3}$ diterima. Oleh sebab itu, hasil tersebut berhasil membuktikan teori legitimasi yang mendasari penelitian ini

Umur perusahaan berpengaruh signifikan pada pengungkapan sustainability report mengindikasikan bahwa perusahaan yang memiliki umur perusahaan lebih lama cenderung mengungkapkan informasi lebih banyak ke dalam sustainability report untuk tetap mepertahankan legitimasi dari masyarakat maupun para investor. Hasil penelitian ini konsisten dengan penelitian Bhatia \& Tuli (2017) dan Orazalin \& Mahmood (2018) yang menyatakan bahwa umur perusahaan berpengaruh signifikan pada pengungkapan sustainability report.

Hipotesis keempat menyatakan bahwa kepemilikan institusional berpengaruh positif pada pengungkapan sustainability report. Berdasarkan hasil analisis regresi, diperoleh nilai signifikansi 0.120 dan koefisien regresi sebesar 0.060. Hal ini menunjukkan bahwa kepemilikan institusional berpengaruh positif dan tidak signifikan pada pengungkapan sustainability report sehingga $\mathrm{H}_{4}$ ditolak. 
Oleh sebab itu, hasil tersebut tidak berhasil membuktikan teori stakeholder yang mendasari penelitian ini.

Kepemilikan institusional tidak berpengaruh signifikan pada pengungkapan sustainability report mengindikasikan bahwa kepemilikan institusional dalam perusahaan yang diteliti tidak dapat memberi tekanan pada manajemen perusahaan untuk mengungkapkan informasi mengenai tanggung jawab sosialnya. Hasil penelitian ini konsisten dengan penelitian yang dilakukan oleh Pratama (2015); Situmorang (2016); Dewi \& Pitriasari (2019) yang menyatakan bahwa kepemilikan institusional tidak berpengaruh signifikan pada pengungkapan sustainability report.

\section{SIMPULAN}

Berdasarkan hasil penelitian yang diperoleh melalui pengujian statistik dan pembahasan seperti yang telah diuraikan sebelumnya, maka dapat disimpulkan bahwa, profitabilitas berpengaruh negatif dan tidak signifikan pada pengungkapan sustainability report, hal ini berarti profitabilitas bukan merupakan faktor yang dapat mempengaruhi pengungkapan sustainability report. Banyaknya item yang diungkapkan ke dalam sustainability report dalam penelitian ini tidak ditentukan berdasarkan tingkat profitabilitas yang dimiliki oleh perusahaan, ukuran perusahaan berpengaruh negatif dan signifikan pada pengungkapan sustainability report, hal ini berarti ukuran perusahaan bukan merupakan faktor yang dapat mempengaruhi pengungkapan sustainability report. Banyaknya item yang diungkapkan ke dalam sustainability report dalam penelitian ini tidak ditentukan berdasarkan ukuran dari perusahaan, umur perusahaan berpengaruh positif dan signifikan pada pengungkapan sustainability report, hal ini berarti umur perusahaan merupakan faktor yang dapat mempengaruhi sustainability report. Semakin lama umur perusahaan, maka semakin banyak item yang akan diungkapkan pada sustainability report, dan kepemilikan institusional berpengaruh positif dan tidak signifikan pada pengungkapan sustainability report, hal ini berarti kepemilikan institusional bukan merupakan faktor yang dapat mempengaruhi pengungkapan sustainability report. Banyaknya item yang diungkapkan ke dalam sustainability report dalam penelitian ini tidak dipengaruhi oleh tingkat kepemilikan institusional yang terdapat pada perusahaan.

Melihat nilai adjusted $R$ square yang rendah dalam penelitian ini, yaitu sebesar 0.121 atau $12.1 \%$ yang menunjukkan bahwa masih banyak faktor-faktor lain yang mempengaruhi pengungkapan sustainability report selain profitabilitas, ukuran perusahaan, umur perusahaan, dan kepemilikan institusional. Peneliti selanjutnya diharapkan dapat menambahkan faktor-faktor lain yang dapat mempengaruhi pengungkapan sustainability report. Berdasarkan hasil penelitian ini, umur perusahaan berpengaruh positif dan signifikan sehingga diharapkan pemerintah dapat membantu mendorong perusahaan baru agar memiliki semangat untuk mengungkapkan sustainability report yang lebih baik dengan membuat regulasi serta pedoman yang dapat digunakan seluruh perusahaan. Berdasarkan hasil penelitian ini, investor disarankan agar tidak hanya memerhatikan perusahaan dari segi ekonominya saja melainkan dapat menjadikan pengungkapan informasi sosial dan lingkungan dalam sustainability 
report sebagai referensi dalam pengambilan keputusan berinvestasi sehingga perusahaan nantinya akan lebih termotivasi untuk mengungkapkan lebih banyak informasi ke dalam sustainability report.

\section{REFERENSI}

Adiatma, K. B., \& Suryanawa, I. K. (2018). Pengaruh Tipe Industri, Kepemilikan Saham Pemerintah, Profitabilitas Terhadap Sustainability Report. E-Jurnal Akuntansi, 25, 934. https:// doi.org/10.24843/eja.2018.v25.i02.p05

Afsari, R., \& Purnamawati, I. G. A. (2017). Pengaruh Leverage, Ukuran Perusahaan, Komite Audit Dan Kepemilikan Institusional Terhadap Luas Pengungkapan Sustainability Report. Jurnal Imiah Mahasiswa Akuntansi Undiksha, 8(2), 1-12.

Aliniar, D. (2017). Pengaruh Mekanisme Good Corporate Governance dan Ukuran Perusahaan Terhadap Kualitas Pengungkapan Sustainability Report Pada Perusahaan Terdaftar di BEI. KOMPARTEMEN, 15(1).

Barung, M. (2018). Pengaruh Mekanisme Good Corporate Governance dan Ukuran Perusahaan Terhadap Kualitas Pengungkapan Sustainability Report (Studi Empiris Pada Seluruh Perusahaan yang Listing di BEI Periode 20112016). Jurnal Akuntansi \& Keuangan Daerah, 13(276-89).

Bhatia, A., \& Tuli, S. (2017). Corporate Attributes Affection Sustainability Reporting: in Indian Perspective. Jurnal of Low and Management, 59.

Budirahardjo, R. (2019). Dilema Sustainability Report Untuk Pembangunan Berkelanjutan. Retrieved from news.unika.ac.id

Dewi, N. K. A. T. (2019). Pengaruh Ukuran Perusahaan, Leverage, dan Profitabilitas Pada CSR Disclosure. E-Jurnal Akuntansi Universitas Udayana, 27(3), 1956-1982.

Dowling, J., \& Pfeffer, J. (1975). Organisational Legitimacy: Social Values and Organisational Behavior. Pacijic Socialogical Review, 18.

Dwipayadnya, P. A., Wiagustini, N. L. P., \& Purbawangsa, I. B. A. (2015). Kepemilikan Manajerial dan Leverage Sebagai Prediktor Profitabilitas pada Pengungkapan Corporate Social Responsibility. Jurnal Buletin Studi Ekonomi, 20(2).

Freeman, R. E. (1984). Strategic Management: A Stakeholder Approach. Pitman Publishing Inc.

Greenpeace Indonesia. (2016). Konsekuensi Tersembunyi: Valuasi Kerugian Ekonomi Akibat Pencemaran. Retrieved from https://www.greenpeace.org

Hidayat, W. W. (2017). The Influence of Size , Return on Equity , and Leverage on the disclosure of the Corporate Social Responsibility ( CSR ). International Journal of Education and Research, 5(8), 57-66.

Khafid, M. (2015). Kontribusi Karakteristik Perusahaan dan Corporate Governance terhadap Publikasi Sustainability Report. Jurnal Ekonomi Dan Keuangan, 19(3), 340-359.

Liana, S. (2019). Pengaruh Profitabilitas, Leverage, Ukuran Perusahaan, dan Dewan Komisaris Independen terhadap Pengungkapan Sustainability Report. Jurnal Ekonomi \& Ekonomi Syariah, 2(2).

Lucia, \& Panggabean, R. R. (2018). the Effect of Firm' S Characteristic and Corporate Governance to Sustainability Report Disclousure. Social Economic 
and Ecology International Journal, 2(1), 18-28.

Majeed, S., Aziz, T., \& Saleem, S. (2015). The Effect of Corporate Governance Elements on Corporate Social Responsibility (CSR) Disclosure: An Empirical Evidence from Listed Companies at KSE Pakistan. International Journal of Financial Studies, 3(4), 530-556. https://doi.org/10.3390/ijfs3040530

Marthin, Marthen B. Salinding, I. A. (2017). Implementasi Prinsip Corporate Social Responsibility Berdasarkan Undang-undang No 40 Tahun 2007 Tentang Perseroan Terbatas. Journal of Private and Commercial Law, 1(1), 111132.

Meutia, F. (2019). Pengaruh Profitabilitas, Leverage, Ukuran Perusahaan, dan Kepemilikan Publik terhadap Pengungkapan Laporan Keberlanjutan. EProceeding of Management, 6(2), 3544.

Novitaningrum, F. (2017). Analysis of Good Corporate Governance Principle (Institusional Ownership, Managerial Ownership, IndependentCommissioners, dan Audit Comittee) to Disclosure Sustainability Report through ROA as Moderating Variabel. Journal of Management, 3(3), 75-79.

Orazalin, N., \& Mahmood, M. (2018). Economic, Environmental, and Social Performance Indicators of Sustainability Reporting: Evidence from The Russian Oil and Gas Industry. Energy Policy, 121, 70-79. https://doi.org/https://doi.org/10.1016/j.enpol.2018.06.015

Rahmadi. (2018). Walhi: Kondisi Indonesia Masih Darurat Ekologis. Retrieved from Mongabay.co.id

Rohmah, D. (2016). Faktor-fakttor yang Mempengaruhi Corporate Social Responsibility di Dalam Laporan Sustainability (Studi Empiris Pada Perusahaan yang listing di Bursa Efek Indonesia Tahun 2010-2013). Esensi, 5(2), 243-262. https://doi.org/10.15408/ess.v5i2.2347

Saturi, S. (2019). Sexy Killer, Ketika Industri Batubara Hnacurkan Lingkungan dan Ruang Hidup Warga. Retrieved from www.mongabay.co.id

Setiawan, K. (2019). Pengaruh Profitabilitas, Solvabilitas, dan Ukuran Perusahaan terhadap Pengungkapan Sustainability Report. Jurnal Akuntansi Dan Keuangan Magister Ilmu Akuntansi Universitas Jambi, 4(2), 30-40.

Situmorang, R. (2016). Pengaruh Karakteristik Dewan Dan Struktur Kepemilikan Terhadap Luas Pengungkapan Sustainability Reporting. Diponegoro Journal Of Accounting, 8(April 2012), 1-14.

Solikhah, B. (2016). an Overview of Legitimacy Theory on The Influence of Company Size and Industry Sensitivity Towards CSR Disclosure. International Journal of Applied Business and Economic Research, 14(5), 30133023.

Sunaryo, B. A., \& Mahfud, M. K. (2016). Pengaruh Size, Profitabilitas, Leverage, dan Umur Terhadap Pengungkapan Tanggungjawab Sosial Perusahaan (Studi Empiris Perusahaan Manufaktur yang Listing di BEI TAHUN 2010 2013). Diponegoro Journal of Management, 5(2), 1-14.

Syofyan, E. (2016). Pengaruh Corporate Governance dan Karakteristik Perusahaan Terhadap Pengungkapan Sustainability Report: Studi Empiris pada Perusahaan yang Terdaftar di BEI tahun 2010-2014. Jurnal WRA, 4(2).

Wijayana, E. (2018). Pengaruh Corporate Governance, Return on Asset Dan 
Umur Perusahaan Terhadap Luas Pengungkapan Sustainability Report. Jurnal Akuntansi Bisnis, 11(2), 157-171. https://doi.org/10.30813/jab.v11i2.1388 